\title{
Front Matter: Volume 6491
}

, "Front Matter: Volume 6491," Proc. SPIE 6491, Videometrics IX, 649101 (29 January 2007); doi: $10.1117 / 12.725478$

SPIE. Event: Electronic Imaging 2007, 2007, San Jose, CA, United States 


\section{PROCEEDINGS OF Electronic Imaging \\ Science and Technology}

\section{Videometrics IX}

J.-Angelo Beraldin

Fabio Remondino

Mark R. Shortis

Chairs/Editors

29-30 January 2007

San Jose, California, USA

Sponsored and Published by

IS\&T-The Society of Imaging Science and Technology

SPIE-The International Society for Optical Engineering 
The papers included in this volume were part of the technical conference cited on the cover and title page. Papers were selected and subject to review by the editors and conference program committee. Some conference presentations may not be available for publication. The papers published in these proceedings reflect the work and thoughts of the authors and are published herein as submitted. The publishers are not responsible for the validity of the information or for any outcomes resulting from reliance thereon.

Please use the following format to cite material from this book:

Author(s), "Title of Paper," in Videometrics IX, edited by J.-Angelo Beraldin, Fabio Remondino, Mark R. Shortis, Proceedings of SPIE-IS\&T Electronic Imaging, SPIE Vol. 6491, Article CID Number (2007).

ISSN 0277-786X

ISBN 9780819466044

Copublished by SPIE-The International Society for Optical Engineering

P.O. Box 10, Bellingham, Washington 98227-0010 USA

Telephone 1 360/676-3290 (Pacific Time) · Fax 1 360/647-1445

http://www.spie.org

and

IS\&T-The Society for Imaging Science and Technology

7003 Kilworth Lane, Springfield, Virginia, 22151 USA

Telephone 1 703/642-9090 (Eastern Time) · Fax 1 703/642-9094

http://www.imaging.org

Copyright @ 2007, The Society of Photo-Optical Instrumentation Engineers and The Society for Imaging Science and Technology.

Copying of material in this book for internal or personal use, or for the internal or personal use of specific clients, beyond the fair use provisions granted by the U.S. Copyright Law is authorized by SPIE and IS\&T subject to payment of copying fees. The Transactional Reporting Service base fee for this volume is $\$ 15.00$ per article (or portion thereof), which should be paid directly to the Copyright Clearance Center (CCC), 222 Rosewood Drive, Danvers, MA 01923. Payment may also be made electronically through CCC Online at http://www.copyright.com. Other copying for republication, resale, advertising or promotion, or any form of systematic or multiple reproduction of any material in this book is prohibited except with permission in writing from the publisher. The CCC fee code is 0277-786X/07/ $\$ 15.00$.

Printed in the United States of America. 


\section{Contents}

$\begin{array}{ll}\text { vii } & \text { Conference Committee } \\ \text { ix Introduction }\end{array}$

\section{SESSION 1 3D SENSING: VIDEOMETRICS}

649103 3D surveillance system using multiple cameras [6491-02]

A. K. Mishra, B. Ni, S. Winkler, A. Kassim, National Univ. of Singapore (Singapore)

649104 On the performance evaluation of tracking systems using multiple pan-tilt-zoom cameras [6491-03]

X. Desurmont, Multitel ASBL (Belgium); J. Hayet, Univ. of Liège (Belgium); C. Machy,

J.-F. Delaigle, Multitel ASBL (Belgium); J.-F. Macq, UCL (Belgium)

649105 Sensor configuration for coverage optimization in surveillance applications [6491-04]

F. Janoos, R. Machiraju, R. Parent, J. W. Davis, A. Murray, The Ohio State Univ. (USA)

\section{SESSION 2 3D SENSING: RANGE SENSING I}

649106 More than a poplar plank: the shape and subtle colors of the masterpiece Mona Lisa by Leonardo (Invited Paper) [6491-05]

F. Blais, J. Taylor, L. Cournoyer, M. Picard, L. Borgeat, G. Godin, J.-A. Beraldin, M. Rioux, National Research Council Canada (Canada); C. Lahanier, B. Mottin, Ctr. de Recherche et de Restauration des Musées de France (France)

649107 Low-cost characterization of 3D laser scanners [6491-06]

M. Russo, G. Morlando, G. Guidi, Politecnico di Milano (Italy)

649108 Metrological verification of 3D scanners: a preliminary approach [6491-07]

R. Anchini, G. Di Leo, C. Liguori, A. Paolillo, A. Pietrosanto, Univ. of Salerno (Italy);

G. Strazzullo, Fox Bit S.p.A. (Italy)

Pagination: Proceedings of SPIE follow an e-First publication model, with papers published first online and then in print and on CD-ROM. Papers are published as they are submitted and meet publication criteria. A unique, consistent, permanent citation identifier (CID) number is assigned to each article at the time of the first publication. Utilization of CIDs allows articles to be fully citable as soon they are published online, and connects the same identifier to all online, print, and electronic versions of the publication.

SPIE uses a six-digit CID article numbering system in which:

- The first four digits correspond to the SPIE volume number.

- The last two digits indicate publication order within the volume using a Base 36 numbering system employing both numerals and letters. The CID number appears on each page of the manuscript. The complete citation is used on the first page, and an abbreviated version on subsequent pages. 
649109 TOF laser scanner characterization for low-range applications [6491-08]

G. Guidi, Politecnico di Milano (Italy); C. Bianchini, Univ. of Rome La Sapienza (Italy)

SESSION 3 3D SENSING: RANGE SENSING II

64910A Real-time range imaging by phase-stamp method using correlation image sensor [6491-10]

A. Kimachi, Osaka Electro-Communication Univ. (Japan); S. Ando, The Univ. of Tokyo (Japan)

64910B Traceable 3D imaging metrology [6491-11]

J.-A. Beraldin, M. Rioux, L. Cournoyer, F. Blais, M. Picard, J. Pekelsky, National Research

Council Canada (Canada)

64910C Range imaging technology: new developments and applications for people identification and tracking [6491-12]

T. Kahlmann, F. Remondino, S. Guillaume, ETH Zürich (Switzerland)

64910D Heterodyne range imaging as an alternative to photogrammetry [6491-13]

A. Dorrington, M. Cree, Univ. of Waikato (New Zealand); D. Carnegie, Victoria Univ. of

Wellington (New Zealand); A. Payne, R. Conroy, Univ. of Waikato (New Zealand)

SESSION 4 3D PROCESSING AND MODELING

64910F Content-based retrieval aided registration for texture images and range images [6491-15]

E. Paquet, J.-A. Beraldin, National Research Council Canada (Canada)

64910G A master-slaves volumetric framework for 3D reconstruction from images [6491-16]

D. Ruiz, B. Macq, Univ. Catholique de Louvain (Belgium)

$64910 \mathrm{H}$ Data acquiring support system using recommendation degree map for 3D outdoor modeling [6491-17]

T. Asai, M. Kanbara, N. Yokoya, Nara Institute of Science and Technology (Japan)

649101 A multinational deployment of 3D laser scanning to study craniofacial dysmorphology in fetal alcohol spectrum disorders [6491-18]

J. Rogers, E. Wernert, Indiana Univ. (USA); E. Moore, St. Vincent Hospital (USA); R. Ward, Indiana Univ. School of Liberal Arts (USA); L. F. Wetherill, T. Foroud, Indiana Univ. School of Medicine (USA)

64910J Measurement and modeling of 4D live mouse heart volumes from CT time series [6491-19] A. W. Wetzel, Pittsburgh Supercomputing Ctr. (USA); C. T. Badea, Duke Univ. Medical Ctr. (USA); S. M. Pomerantz, Pittsburgh Supercomputing Ctr. (USA); N. Mistry, Duke Univ. Medical Ctr. (USA); D. Nave, Pittsburgh Supercomputing Ctr. (USA); G. A. Johnson, Duke Univ. Medical Ctr. (USA) 
64910K Concepts of single highspeed-camera photogrammetric 3D measurement systems (Invited Paper) [6491-20]

H.-G. Maas, Dresden Univ. of Technology (Germany)

64910L Configuration of multimirror systems for single high-speed camera based 3D motion analysis [6491-21]

T. Putze, Technische Univ. Dresden (Germany); K. Raguse, Volkswagen AG (Germany);

H.-G. Maas, Technische Univ. Dresden (Germany)

64910M Gait analysis in forensic medicine [6491-22]

P. K. Larsen, E. B. Simonsen, N. Lynnerup, Univ. of Copenhagen (Denmark)

649100 3D body scanning technology for fashion and apparel industry [6491-24]

N. D'Apuzzo, Homometrica Consulting (Switzerland)

64910P Single CMOS sensor system for high resolution double volume measurement applied to membrane distillation system [6491-25]

M. G. Lorenz, Univ. Carlos III (Spain); M. A. Izquierdo-Gil, Univ. Complutense (Spain);

R. Sanchez-Reillo, Univ. Carlos III (Spain); C. Fernandez-Pineda, Univ. Complutense (Spain)

$64910 Q \quad$ Beyond inspection: the promise of videometrics for industry and engineering (Invited Paper) [6491-26]

K. L. Edmundson, Geodetic Systems, Inc. (USA)

\section{SESSION 7 CULTURAL HERITAGE}

$64910 \mathrm{R}$ Active and passive sensors for art works analysis and investigations (Invited Paper) [6491-27]

A. Pelagotti, Art-Test (Italy); A. Del Mastio, Univ. of Florence (Italy); A. V. Razionale, Univ. of Pisa (Italy)

$64910 S$ The potential of 3D techniques for Cultural Heritage object documentation [6491-28] G. Bitelli, V. A. Girelli, Univ. of Bologna (Italy); F. Remondino, ETH Zürich (Switzerland); L. Vittuari, Univ. of Bologna (Italy)

$64910 \mathrm{~T}$ Wood artworks monitoring through high-resolution 3D cameras [6491-29] G. Guidi, Politecnico di Milano (Italy); J.-A. Beraldin, National Research Council Canada (Canada); C. Atzeni, Univ. of Florence (Italy)

$64910 U$ Digital documentation of complex architectures by integration of multiple techniques: the case study of Valer Castle [6491-30]

F. Voltolini, ITC-IRST (Italy); S. El-Hakim, National Research Council (Canada); F. Remondino, ETH Zurich (Switzerland); S. Girardi, A. Rizzi, M. Pontin, L. Gonzo, ITC-IRST (Italy) 


\section{SESSION 8 VISUALIZATION}

$64910 \mathrm{~V}$ Performance evaluation of a coded structural light system for cultural heritage applications [6491-31]

D. Akca, F. Remondino, D. Novák, T. Hanusch, G. Schrotter, A. Gruen, ETH Zürich

(Switzerland)

64910W A solid texture analysis based on three-dimensional convolution kernels [6491-32]

M. T. Suzuki, Y. Yaginuma, National Institute of Multimedia Education (Japan)

64910X Acquisition of three-dimensional coordinates of objects from Axi-Vision image data and application to stereoscopic display using integral photography system [6491-33]

T. Aida, A. Yoneda, T. Uragaki, Osaka City Univ. (Japan); M. Kawakita, Japan Broadcasting

Corp. (Japan)

64910Y Crack propagation imaging by the ISIS camera and a video trigger system [6491-34]

T. Okinaka, P. Karimov, T. Ełoh, Kinki Univ. (Japan); K. Oguni, Univ. of Tokyo (Japan)

\section{POSTER SESSION}

$64910 Z$ Variability of bodily measures of normally dressed people using PhotoModeler Pro. [6491-39]

P. K. Larsen, Univ. of Copenhagen (Denmark); L. Hansen, National Institute of Occupational Health (Denmark); E. B. Simonsen, N. Lynnerup, Univ. of Copenhagen (Denmark)

649110 Subpixel location of discrete target images in close-range camera calibration: a novel approach [649]-40]

R. Anchini, Univ. of Salerno (Italy); J. A. Beraldin, National Research Council Canada

(Canada); C. Liguori, Univ. of Salerno (Italy)

649111 Design of an image sensor for an ultra-high-speed and ultra-high-sensitive video microscope [649]-42]

N. Otsuka, V. L. Cuong, P. Karimov, K. Takehara, T. G. Ełoh, Kinki Univ. (Japan)

649112 Performance analysis and parameter optimization for iris recognition using Log-Gabor wavelet [649]-43]

V. A. Pozdin, Y. Du, Indiana Univ.-Purdue Univ. (USA)

Author Index 


\title{
Conference Committee
}

\author{
Symposium Chairs \\ Michael A. Kriss, Consultant (USA) \\ Robert A. Sprague, Consultant (USA) \\ Conference Chairs
}

J.-Angelo Beraldin, National Research Council Canada (Canada) Fabio Remondino, ETH Zürich (Switzerland)

Mark R. Shortis, RMIT University (Australia)

Program Committee

Hirofumi Chikatsu, Tokyo Denki University (Japan)

Sabry F. El-Hakim, National Research Council Canada (Canada)

Alan M. Frank, Lawrence Livermore National Laboratory (USA)

Dieter Fritsch, Universität Stuttgart (Germany)

Joao G. M. Goncalves, European Commission (Italy)

Armin Gruen, ETH Zürich (Switzerland)

Gabriele Guidi, Politecnico di Milano (Italy)

Graham P. Haddleton, QinetiQ (United Kingdom)

Henrik G. A. Haggren, Helsinki University of Technology (Finland)

George I. Karras, National Technical University of Athens (Greece)

Hans-Gerd Maas, Technische Universität Dresden (Germany)

Lars S. Nyland, University of North Carolina/Chapel Hill (USA)

Stuart Robson, University College London (United Kingdom)

Luc J. Van Gool, Katholieke Universiteit Leuven (Belgium)

James S. Walton, 4DVIDEO (USA)

\section{Session Chairs}

1 3D Sensing: Videometrics

Hans-Gerd Maas, Technische Universität Dresden (Germany)

2 3D Sensing: Range Sensing I

J.-Angelo Beraldin, National Research Council Canada (Canada)

3 3D Sensing: Range Sensing II

François Blais, National Research Council Canada (Canada)

$4 \quad 3 D$ Processing and Modeling

Fabio Remondino, ETH Zürich (Switzerland) 
5 Motion Analysis

Fabio Remondino, ETH Zürich (Switzerland)

6 Industry

Gabriele Guidi, Politecnico di Milano (Italy)

7 Cultural Heritage

Mark R. Shortis, Royal Melbourne Institute of Technology (Australia)

8 Visualization

Nicola D'Apuzzo, Homometrica Consulting (Switzerland) 


\section{Introduction}

This Videometrics conference is 11 th in a series begun in 1991. Under the auspices of SPIE-The International Society for Optical Engineering, Sabry El-Hakim arranged the first conference on Industrial Vision Metrology at Winnipeg in Canada. Based on the success of this first venture into the emerging discipline, the conference was renamed Videometrics and held in conjunction with the SPIE Photonics East symposium in Boston and Philadelphia during 1992-1995. Videometrics was then relocated among the approximately 20 conferences composing the IS\&T/SPIE Electronic Imaging symposium (jointly sponsored by IS\&T-Society for Imaging Science and Technology and SPIE), collocated with SPIE's Photonics West event held annually in California. The conferences were held once in San Diego, in 1997, then twice in San Jose, in 1999 and 2000, and given the longer title of "Videometric and Optical Methods for 3D Shape Measurement."

In 2003, Electronic Imaging was geographically separated from Photonics West, primarily because the event had become too large to be easily accommodated in available convention facilities in California. Electronic Imaging was held in Santa Clara in 2003, and moved back to San Jose in 2005. Since then the two symposia both have been held in San Jose, but in consecutive weeks.

The Electronic Imaging conferences combine the disciplines of 3D imaging, visualisation, image processing, digital image sensors, multimedia processing, and video communications. Although the individual conferences generally span one to three days, the schedule is staggered so that there is a selection of 15-20 technical sessions at any time during the meeting. Attendees thereby get the benefit of seeing the broader extent of discipline areas allied to Videometrics.

During the last 15 years, Videometrics has provided a unique forum for computer vision and photogrammetry practitioners to present the latest advances in precise 3D measurement and modelling from imaging and range sensors. Videometrics was originally focused on the metric performance of sensors and algorithms to produce the most accurate and reliable geometric measurements and models. Topics such as sensor calibration, performance evaluation, and accurate object reconstruction were paramount. This has now been expanded to encompass all phases of 3D imaging and modelling of real scenes including automation of data collection and processing, improving the visual quality and realism, visualization, animation, and data management for real-time manipulation. This is in response to the rapidly growing interest in 3D imaging and modelling technology, and the increase in demand of such models in applications such as rapid product development, virtual museums, documentation of monuments and architecture for cultural heritage, marketing 
and tourism, human body modelling, medicine, and exploration of remote and hazardous sites, to name a few.

The chairs of Videometrics welcome and acknowledge the efforts of the authors, presenters, and audience in maintaining the high level of interest in Videometrics and contributing to the success of the meeting.

J.-Angelo Beraldin Fabio Remondino

Mark R. Shortis 